\title{
The effect of repeated episodes of bacteria-specific clinical mastitis on mortality and culling in Holstein dairy cows
}

\author{
E. Cha, ${ }^{* 1}$ J. A. Hertl, ${ }^{*}$ Y. H. Schukken, ${ }^{*}$ L. W. Tauer,† F. L. Welcome, $\ddagger$ and Y. T. Gröhn* \\ *Section of Epidemiology, College of Veterinary Medicine, \\ †Charles H. Dyson School of Applied Economics and Management, College of Agriculture and Life Sciences, and \\ ‡Quality Milk Production Services, College of Veterinary Medicine, Cornell University, Ithaca, NY 14853
}

\section{ABSTRACT}

The objective of this study was to estimate the effect of a first and repeated cases of bacteria-specific clinical mastitis (CM) on the risk of mortality and culling in Holstein dairy cows. The pathogens studied were Streptococcus spp., Staphylococcus aureus, Staphylococcus spp., Escherichia coli, Klebsiella spp., Trueperella pyogenes, others, and no growth on aerobic culture. A total of 50,166 lactations were analyzed from 5 large, high-milk-producing dairy herds in New York State from 2003/2004 to 2011. Generalized linear mixed models with a Poisson error distribution were used to study the effects of parity, month of lactation, CM, calving diseases, pregnancy status, current season, and economic values on the risk of mortality and culling. Among first-lactation cows, the presence of a first CM case generally exposed cows to a greater risk of mortality in the current month (compared with the absence of a first case). This was especially acute with a first case of Klebsiella spp., where cows were 4.5 times more at risk [95\% confidence interval (CI): 2.7-7.6] of mortality, and with a first case of $E$. coli were 3.3 times more at risk (95\% CI: 2.5-4.5). In first-parity cows, the risk of culling generally increased with a case of bacteriaspecific CM. This was observed among cows with a first case of $T$. pyogenes [relative risk $=10.4(95 \%$ CI: 8.4-12.8)], a first case of Klebsiella spp. [relative risk $=6.7$ (95\% CI: 5.5-8.1)], a first case of Staph. aureus [relative risk $=4.8$ (95\% CI: 2.7-8.4)], a first case of $E$. coli [relative risk $=3.1(95 \%$ CI: $2.7-3.6)$ ], and a third case of Klebsiella spp. [relative risk $=5.0$ (95\% CI: 3.1-8.0)]. In general, the presence of a first or second/ third case resulted in cows in parity $\geq 2$ with a greater risk of mortality. This was greatest for cows with a first case of Klebsiella spp. [relative risk $=3.7$ (95\% CI: 3.3-4.3)], followed by a second/third case of Klebsiella spp. [relative risk $=3.2(95 \%$ CI: $2.5-4.0)]$, a first case of $E$. coli [relative risk $=3.0(95 \%$ CI: $2.7-3.3)$ ], and a

Received October 4, 2012.

Accepted April 30, 2013.

${ }^{1}$ Corresponding author: elvacha@gmail.com first case of other CM [relative risk $=1.8(95 \%$ CI: $1.6-$ $2.0)]$. Among cows of parity $\geq 2$, the risk of culling was greater for cows as they progressed through lactations [i.e., cows in parity $4+$ were 2.1 (95\% CI: 2.0-2.2) times more likely to be culled compared with cows in lactation 2 (the baseline)]. The risk of culling dependent on the cow's characteristics can be easily calculated from the parameter estimates in the provided tables.

Key words: mortality, culling, bacteria specific, mastitis

\section{INTRODUCTION}

Mastitis is one of the top 3 reasons for culling dairy cows, alongside lameness and failure to conceive (Esslemont and Kossaibati, 1997). The effects of mastitis include reduced conception (Hertl et al., 2010), losses to milk yield (Schukken et al., 2009), a higher risk of mortality (Bar et al., 2008a; Hertl et al., 2011), and, depending on the pathogen involved, significant treatment costs. In addition to the presence of disease, the dairy farmer considers milk yield, conception status, stage of lactation and parity when making a decision (Gröhn et al., 1998; Rajala-Schultz and Gröhn, 1999). From this perspective, studies have been performed to identify the cost of mastitis and economically optimal management decisions (Halasa et al., 2009; Sørensen et al., 2010). Farmers may justify that it is economically optimal to replace their diseased cows with newly calved first-lactation animals, in anticipation of accrued losses to production over their projected lifespan (Houben et al., 1994; Bar et al., 2008b; Cha et al., 2011) and management of milk quality.

To estimate the cost of mastitis, it becomes necessary to separate those events that are beyond the control of the dairy farmer from those events that are within the dairy farmer's control. Mortality is a forced event that occurs with a given probability, whereas culling or selling a cow is a decision that may be an economic decision made by a dairy farmer depending on the specific cow involved (Houben et al., 1994; Bar et al., 2008a,b).

The risk of mortality and culling is dependent on the pathogen causing the clinical mastitis (CM), the 
repeatability of cases, seasonality, and cow characteristics. For example, a study of mortality among Danish dairy cattle showed that the most-frequent specific diagnosis among udder/teat disorders resulting in death was septic mastitis caused by Escherichia coli (Thomsen et al., 2004). Hazlett et al. (1984) similarly found that E. coli, followed by Klebsiella spp. were the most common causes of fatal mastitis. The severity of mastitis has been shown to be calendar time dependent; Bradley and Green (2001) demonstrated that E. coli mastitis had a tendency of being more severe between October and March than between April and September in the Northern hemisphere. The authors reason that this may be due to alterations in pathogenicity of the organisms present among environmental pathogens at various times of the year (Bradley and Green, 2001). A trend also existed toward more severe mastitis occurring in the first $90 \mathrm{~d}$ of lactation than in the latter periods of lactation. This parallels the findings of Lehtolainen et al. (2003), where cows' responses, defined by local and systemic signs to intramammarily infused $E$. coli endotoxin, were significantly more severe in early lactation than late lactation. We have studied the risk of repeated cases of bacteria-specific CM and have found that a previous case with the same pathogen will put cows at greater risk of a subsequent case (Schukken et al., 2009). Earlier, Bradley and Green (2001) reported similar results [i.e., repeat cases of CM occurred in 46 (16.4\%) of affected quarters and in 24 (8.6\%), the repeat cases were due to the same species of pathogens as the initial case]. Although previous studies have examined the effects of repeated episodes of non-bacteriaspecific CM (Bar et al., 2008a), repeated episodes of gram-positive, gram-negative, and other CM (Hertl et al., 2011) and a first case of pathogen-specific CM on mortality and culling in dairy cows (Hazlett et al., 1984; Gröhn et al., 2005), no study has investigated the role of repeated cases of pathogen-specific CM. Specifically, it is unclear if repeated cases of the same pathogen and if a shorter time interval between repeated cases put cows at a greater risk of being culled. Therefore, the objective of this study was to estimate the effect of a first and repeated cases of bacteria-specific $\mathrm{CM}$ on the risk of mortality and culling in Holstein dairy cows.

\section{MATERIALS AND METHODS}

\section{Herd Descriptions}

Data from 50,166 lactations were assembled (18,420 of parity 1 and 31,746 of parity 2 and greater) from 23,409 cows. The data in this study were collected from 2003/2004 to 2011 (7-8 yr) from 5 large dairy herds in New York State. The 305-d rolling herd average milk production ranged from 11,260 to $13,123 \mathrm{~kg} / \mathrm{cow}$ per year, and the monthly mean SCC ranged from 137,000 to 262,000 cells $/ \mathrm{mL}$.

Cows were housed in freestalls. Feed was provided in the feed alleys with headlocks, which facilitated the treatment and examination of cows. Cows were stratified by lactation, production, and reproductive status into feeding groups that were fed a TMR. Cows were milked 3 times per day and the milking units automatically recorded milk production. Lactation, reproductive, and medical information was entered into DairyComp305 herd management software (Valley Agricultural Software, Tulare, CA) by herd personnel. Information on parity, diseases, drying off, calving, and exit from all herds was available, as it was used by herd personnel for management of the dairy (Bar et al., 2008a; Hertl et al., 2011).

The variables relating to milk yield, mastitis culture results, diseases, and reproduction necessary to conduct this study were exported to ASCII files from DairyComp305 and imported into SAS v. 9.2 software (SAS Institute, 2008). The quality of the data was assessed through preliminary descriptive analyses of the variables of interest.

\section{Case Definition}

All lactating cows in the 5 herds were eligible for inclusion in the study. Cows were identified as having CM based on (1) milkers observing clinical signs of CM (i.e., a warm, swollen udder or changes in milk color or consistency); (2) otherwise, the remaining cases that were missed by milkers were identified by herdspersons who examined cows due to elevated milk electrical conductivity in addition to a sudden concurrent milk loss (at the cow level) as alerted by the farm computer system (Maatje et al., 1992; Nielen et al., 1995; Norberg et al., 2004). The treatment protocol for diseased cows was similar across the 5 dairy herds and throughout the study. Herd personnel collected milk samples from quarters with signs of CM for microbiological culturing at the Quality Milk Production Services laboratories located in NY State. The culture procedures are described in more detail in Gröhn et al. (2004). Briefly, milk samples were plated by streaking $0.01 \mathrm{~mL}$ on Trypticase soy agar II with 5\% sheep blood and 0.1\% esculin (BBL; Becton Dickinson Microbiology Systems, Cockeysville, MD). Plates were incubated at $37^{\circ} \mathrm{C}$ for $48 \mathrm{~h}$. Following observation of colony morphology and hemolytic patterns on blood agar, isolates were examined by means of $3 \% \mathrm{KOH}$, Gram-staining organisms, catalase and oxidase testing, and additional biochemical and metabolic evaluations as required. Colony morphology on MacConkey agar and the BBL Crystal ID 
System (Becton Dickinson Microbiology Systems) identified gram-negative organisms. Streptococci that had a negative Christie, Atkins, Munch-Petersen (CAMP) reaction were classified as Streptococcus spp. Staphylococci with $\beta$ or $\alpha \beta$ hemolytic patterns that had a positive tube test for free coagulase were classified as Staphylococcus aureus. Nonhemolytic staphylococci with a positive tube coagulase test were further identified with the API Staph System (bioMérieux Vitek, Hazelwood, MO). Coagulase-negative staphylococci were classified as Staphylococcus spp.

The unit of observation was month within the lactation of a cow. Some cows experienced 2 types of bacteria-specific $\mathrm{CM}$ that were isolated within the same lactation within a few days of each other. If the second pathogen was isolated in the same quarter 5 or fewer days after the first pathogen (regardless of the pathogen isolated) or occurred within $14 \mathrm{~d}$ with the same pathogens isolated, it was considered to be the same case of mastitis. Any mastitis case after $14 \mathrm{~d}$ since the previous mastitis case was considered a new case (Barkema et al., 1998). If a cow had multiple quarter infections at the same time (e.g., E. coli in the left rear quarter and Staphylococcus spp. in the right front quarter, or both pathogens in the same quarter), she was considered to have both E. coli and Staphylococcus spp. isolated within the one case (Hertl et al., 2011).

\section{Bacteria-Specific CM}

The bacteria causing CM studied were Streptococcus spp. (these would generally be Streptococcus uberis, Streptococcus dysgalactiae, and other streptococci, but were not speciated for this study), Staph. aureus, Staphylococcus spp., E. coli, Klebsiella spp., Trueperella pyogenes, other CM (i.e., pathogens other than those listed above), and no growth. No-growth cases were defined as either no bacterial growth on the culture plate after aerobic incubation, contaminated sample (more than 2 bacterial organisms on the same plate), or no significant organisms. The latter (no significant organisms) was defined as no bacterial growth of either Staph. aureus or Streptococcus agalactiae while the culture plate contained more than 2 different species.

\section{Other Diseases}

Five other diseases were included as potential confounders. These diseases are among the most-common clinical conditions universally problematic in dairy cows (Gröhn et al., 2004). The 5 diseases included were milk fever, retained placenta, metritis, ketosis, and displaced abomasum (DA). They were defined as follows: (1) milk fever occurred if a cow was unable to rise or had cool extremities and sluggish rumen motility near the time of calving, but was treated successfully with calcium; (2) retained placenta was retention of fetal membranes for at least $24 \mathrm{~h}$ postcalving; (3) metritis involved a febrile state accompanying a purulent or fetid vaginal discharge or diagnosis of an enlarged uterus by veterinary palpation; (4) ketosis was diagnosed by a decrease in feed intake and milk production with detection of ketones in milk, urine, or breath, and no other concomitant diseases and with response to treatment; and (5) DA occurred when the abomasum was enlarged with fluid, gas, or both, and was mechanically trapped in either the left or right side of the abdominal cavity; almost every DA case was confirmed by surgery, but cows removed from the herd without treatment were also recorded. Every effort was made to ensure that disease definition and diagnostic criteria were consistent across herds and written disease definitions were provided to dairy producers and veterinarians involved to assist with diagnosis.

\section{Statistical Methods}

The GLIMMIX procedure of SAS v. 9.2 (SAS Institute, 2008) was used to study the effect of bacteria-specific $\mathrm{CM}$ on the risk of mortality and culling. Variables for inclusion were selected based on univariate analysis where $P \leq 0.20$ was considered significant using stepwise backward elimination; variables of biological importance were also kept. The form of the generalized linear mixed model used was

$$
\operatorname{Ln}(\mu)=\mathbf{X} \boldsymbol{\beta}+\mathbf{Z} \gamma
$$

where $\mathrm{Ln}$ is a link function (natural $\log$ ), $\mu$ is the mean probability of a cow surviving in a given month (given the cow survived through the previous month), $\boldsymbol{\beta}$ is the vector regression coefficients corresponding to a fixed-effects matrix $\mathbf{X}$, and $\boldsymbol{\gamma}$ is an unknown vector of random-effect parameters with matrix of herd indicators $\mathbf{Z}$. The distributional assumptions were that $\mathbf{Y} \mid \mu$ $\sim$ Poisson and $\gamma \sim \mathrm{N}\left(0, \sigma^{2}\right)$, where $\mathbf{Y}$ is a vector of observations (presence or absence of mortality or culling in 1 mo) and $\sigma^{2}$ is the variance of the normally distributed $\gamma$. Fixed effects in our models were parity, with 3 levels (for multiparous cows; i.e., second, third, and fourthand-greater lactation); stage of lactation (mo 1 to 10); current season, with 4 levels [summer (June to August), fall (September to November), winter (December to February), and spring (March to May)]; pregnancy status (yes or no); other diseases, with 2 levels (presence or absence); and bacteria-specific CM indices (described below). The selection of these periods is informative but also based upon needs of a later economic model 
to be constructed using the estimates. For the culling analysis, fixed effects also included monthly profitability and monthly net replacement cost. Monthly profitability was defined to be monthly milk price minus the monthly operating cost. Milk prices were obtained from the US Department of Agriculture (USDA; USDANASS, 2012) for each month of observation in the data set, and are wholesale prices $(\$ / \mathrm{cwt}$ ) received by New York farmers. Operating costs were obtained from the USDA (USDA-ERS, 2010, 2012) for each month of observation and are the monthly dairy costs of production per hundredweight of milk sold for New York farmers. Monthly net replacement cost was defined as monthly purchase price of replacement minus the monthly cull price of cow. Purchase prices of replacements were obtained from the USDA (USDA-NASS, 2012) for each month of observation. More details can be found in Hertl et al. (2011).

For the mortality analyses, we were particularly interested in estimating the risk of mortality based on the presence or absence of pathogen-specific CM by case (1, 2 , and 3 ) in the current month in milk, whereas in the culling analysis, we were also interested in observing whether the risk of culling was not only greatest in the month of bacteria-specific CM occurrence by case, but also how the risk varied as months passed since the case of bacteria-specific CM. We have previously shown that Poisson modeling of time-to-event data with timedependent covariates has many advantages over other related models (Schukken et al. 2010). We were also interested in obtaining monthly culling risks from these data (see below) for use in economic decision models. For that reason, we compared models with a binomial, Poisson, and negative binomial error distribution in combination with the above-described covariate coding schemes. In instances where such a detailed covariate coding scheme did not allow model convergence in any of these 3 different distributions, alternative covariate coding schemes were explored. The best models were selected, based on whether convergence could be attained at all and the resulting parameters of model fit $(-2 \log$-likelihood and Pearson or generalized chi square/df). The models with the best fit are presented, with fit statistics reported.

For the mortality analysis, each bacteria-specific CM had 2 separate binary variables: (a) $1=$ presence of a first case of bacteria-specific CM in the current month of lactation and $0=$ absence of that bacteria-specific CM case in the current month of lactation and (b) $1=$ presence of a second or third case of bacteria-specific $\mathrm{CM}$ in the current month of lactation and $0=$ absence of a second or third case of that bacteria-specific CM in the current month of lactation (Table 1). For the culling analysis, each case of bacteria-specific CM had 2 binary variables (e.g., for a first case, $1=$ presence of a first case of bacteria-specific CM in the current month of lactation or $1 \mathrm{mo}$ after this first case and $0=$ absence of that bacteria-specific CM in the current month of lactation or 2 or more months since that case; Table 2).

We analyzed the occurrence of CM per cow-month at risk. Because we used such a short time period as our unit of analysis, the distinction between risk and rate diminished. The relationship between risk (cumulative incidence) and rate (incidence) is given as follows:

$$
\text { Cumulative incidence }=1-\exp (- \text { incidence } \times \Delta \mathrm{t}) \text {, }
$$

where $\Delta t$ is the time unit of cow-months. For a small cumulative incidence, a good approximation is incidence $\times \Delta \mathrm{t}$, where $\Delta \mathrm{t}$ in our models equals 1 , and where essentially the cumulative incidence and incidence can then be used interchangeably. For that reason, we use risk as a measure of disease occurrence throughout this paper (Rothman, 1986).

Because we were not interested in specific herds, but rather herds in general, with the common characteristics of being large, high-milk-producing dairy herds with a low incidence of contagious mastitis, we always attempted to include herd as a random effect. Observation periods were censored at a typical lactation of 10 mo or when cows died or were culled.

For the mortality data set, 2 models were fitted: (1a) effects of risk factors (current season, month of lactation, bacteria-specific CM cases, pregnancy status, other diseases, and farm) on the risk of mortality in primiparae, and (1b) effects of risk factors (parity, current season, month of lactation, bacteria-specific CM cases, pregnancy status, other diseases, and farm) on risk of mortality in multiparae. For the culling data set, 2 models were fitted: (2a) effects of risk factors (month of lactation; bacteria-specific CM cases, including time since previous case; pregnancy status; other diseases; economic values; and farm) on the risk of culling in primiparae, and (2b) effects of risk factors (parity; season; month of lactation; bacteria-specific CM cases, including time since previous case; pregnancy status; other diseases; economic values; and farm) on the risk of culling in multiparae. Not all models retained the variables listed in parentheses; a $P$-value below 0.05 was considered significant.

\section{RESULTS}

\section{Descriptive Findings}

The number of observations included 416,016 mo from 50,166 lactations (18,420 of parity 1 and 31,746 of parity 2 and greater from 23,409 cows) on 5 large dairy 
Table 1. Covariate coding scheme used in the multiparous cow mortality analysis: data for 3 example cows with bacteria-specific clinical mastitis (CM)

\begin{tabular}{|c|c|c|c|c|c|c|c|c|c|c|c|c|c|}
\hline $\begin{array}{l}\text { Cow } \\
\text { identification }\end{array}$ & $\begin{array}{l}\text { Month } \\
\text { in milk }\end{array}$ & $\begin{array}{l}\text { Month of } \\
\text { first CM } \\
\text { case }\end{array}$ & $\begin{array}{l}\text { First-case } \\
\text { pathogen }^{1}\end{array}$ & $\begin{array}{l}\text { Month of } \\
\text { second CM } \\
\text { case }\end{array}$ & $\begin{array}{l}\text { Second-case } \\
\text { pathogen }^{1}\end{array}$ & $\begin{array}{l}\text { Month of } \\
\text { third } \\
\text { CM case }\end{array}$ & $\begin{array}{l}\text { Third-case } \\
\text { pathogen }^{1}\end{array}$ & $\begin{array}{l}\text { E. coli } \\
\text { case } 1^{2}\end{array}$ & $\begin{array}{l}\text { E. coli } \\
\text { case } \\
2 \text { or } 3^{2}\end{array}$ & $\begin{array}{l}\text { Staphylococcus } \\
\text { spp. case } 1^{2}\end{array}$ & $\begin{array}{c}\text { Staphylococcus } \\
\text { spp. case } 2 \text { or } 3^{2}\end{array}$ & $\begin{array}{l}\text { Month } \\
\text { died }\end{array}$ & $\begin{array}{l}\text { Died } \\
\text { (no.) }\end{array}$ \\
\hline 1 & 1 & 2 & $\mathrm{EC}$ & 2 & $\mathrm{SP}$ & - & NA & 0 & 0 & 0 & 0 & - & 0 \\
\hline 1 & 2 & 2 & $\mathrm{EC}$ & 2 & SP & - & NA & 1 & 0 & 0 & 1 & - & 0 \\
\hline 1 & 2 & 2 & $\mathrm{EC}$ & 2 & SP & - & NA & 0 & 0 & 0 & 0 & - & 0 \\
\hline 1 & 3 & 2 & $\mathrm{EC}$ & 2 & SP & - & NA & 0 & 0 & 0 & 0 & - & 0 \\
\hline 1 & 4 & 2 & $\mathrm{EC}$ & 2 & SP & - & NA & 0 & 0 & 0 & 0 & - & 0 \\
\hline 2 & 1 & 1 & SP & - & NA & - & NA & 0 & 0 & 1 & 0 & 4 & 0 \\
\hline 2 & 2 & 1 & SP & - & NA & - & NA & 0 & 0 & 0 & 0 & 4 & 0 \\
\hline 2 & 3 & 1 & SP & - & NA & - & NA & 0 & 0 & 0 & 0 & 4 & 0 \\
\hline 2 & 4 & 1 & SP & - & NA & - & NA & 0 & 0 & 0 & 0 & 4 & 1 \\
\hline 3 & 1 & - & NA & - & NA & - & NA & 0 & 0 & 0 & 0 & - & 0 \\
\hline 3 & 2 & - & NA & - & NA & - & NA & 0 & 0 & 0 & 0 & - & 0 \\
\hline 3 & 3 & - & NA & - & NA & - & NA & 0 & 0 & 0 & 0 & - & 0 \\
\hline 3 & 4 & - & NA & - & NA & - & NA & 0 & 0 & 0 & 0 & - & 0 \\
\hline 3 & 5 & - & NA & - & NA & - & NA & 0 & 0 & 0 & 0 & - & 0 \\
\hline 3 & 6 & - & NA & - & NA & - & NA & 0 & 0 & 0 & 0 & - & 0 \\
\hline 3 & 7 & - & NA & - & NA & - & NA & 0 & 0 & 0 & 0 & - & 0 \\
\hline 3 & 8 & - & NA & - & NA & - & NA & 0 & 0 & 0 & 0 & - & 0 \\
\hline 3 & 9 & - & NA & - & NA & - & NA & 0 & 0 & 0 & 0 & - & 0 \\
\hline 3 & 10 & - & NA & - & NA & - & NA & 0 & 0 & 0 & 0 & - & 0 \\
\hline
\end{tabular}

$\overline{\check{c}}{ }^{1}$ Note that a maximum of 2 pathogens is listed because of space limitations. $\mathrm{EC}=$ Escherichia coli; $\mathrm{SP}=$ Staphylococcus spp.; NA $=$ none.

${ }^{2}$ The index variable for cases of $\mathrm{CM}$ had 2 levels: $0=$ absence of that pathogen and case in the current month of lactation; $1=$ presence of that pathogen and case in the current 


\begin{tabular}{|c|c|c|c|c|c|c|c|c|c|c|c|c|c|c|}
\hline $\begin{array}{l}\text { Cow } \\
\text { identification }\end{array}$ & $\begin{array}{l}\text { Month } \\
\text { in milk }\end{array}$ & $\begin{array}{l}\text { Month of } \\
\text { first CM } \\
\text { case }\end{array}$ & $\begin{array}{l}\text { Month of } \\
\text { second } \\
\text { CM } \\
\text { case }\end{array}$ & $\begin{array}{l}\text { Month of } \\
\text { third CM } \\
\text { case }\end{array}$ & $\begin{array}{l}\text { Month } \\
\text { sold }\end{array}$ & $\begin{array}{c}\text { Index } \\
\text { variable for } \\
\text { Streptococcus } \\
\text { spp. CM } \\
\text { case } 2^{2}\end{array}$ & $\begin{array}{c}\text { Index } \\
\text { variable for } \\
\text { Streptococcus } \\
\text { spp. CM } \\
\text { case } 3^{2}\end{array}$ & $\begin{array}{c}\text { Index } \\
\text { variable for } \\
\text { Staphylococcus } \\
\text { spp. CM } \\
\text { case } 1^{2}\end{array}$ & $\begin{array}{c}\text { Index } \\
\text { variable for } \\
\text { E. coli CM } \\
\text { case } 2^{2}\end{array}$ & $\begin{array}{l}\text { Index } \\
\text { variable for } \\
\text { Klebsiella } \\
\text { spp. CM } \\
\text { case } 1^{2}\end{array}$ & $\begin{array}{c}\text { Index } \\
\text { variable } \\
\text { for no } \\
\text { growth } \\
\text { CM case } \\
\quad 1^{2}\end{array}$ & $\begin{array}{c}\text { Index } \\
\text { variable } \\
\text { for no } \\
\text { growth } \\
\text { CM case } \\
\quad 2^{2}\end{array}$ & $\begin{array}{l}\text { Index } \\
\text { variable for } \\
\text { other CM } \\
\text { case } 1^{2}\end{array}$ & $\begin{array}{l}\text { Sold } \\
\text { (no.) }\end{array}$ \\
\hline 1 & 1 & 1 & 2 & - & - & 10 & 10 & 10 & 10 & 10 & 1 & 10 & 10 & 0 \\
\hline 1 & 2 & 1 & 2 & - & - & 10 & 10 & 10 & 1 & 10 & 1 & 10 & 10 & 0 \\
\hline 1 & 3 & 1 & 2 & - & - & 10 & 10 & 10 & 1 & 10 & 10 & 10 & 10 & 0 \\
\hline 1 & 4 & 1 & 2 & - & - & 10 & 10 & 10 & 10 & 10 & 10 & 10 & 10 & 0 \\
\hline 1 & 5 & 1 & 2 & - & - & 10 & 10 & 10 & 10 & 10 & 10 & 10 & 10 & 0 \\
\hline 1 & 6 & 1 & 2 & - & - & 10 & 10 & 10 & 10 & 10 & 10 & 10 & 10 & 0 \\
\hline 1 & 7 & 1 & 2 & - & - & 10 & 10 & 10 & 10 & 10 & 10 & 10 & 10 & 0 \\
\hline 1 & 8 & 1 & 2 & - & - & 10 & 10 & 10 & 10 & 10 & 10 & 10 & 10 & 0 \\
\hline 1 & 9 & 1 & 2 & - & - & 10 & 10 & 10 & 10 & 10 & 10 & 10 & 10 & 0 \\
\hline 1 & 10 & 1 & 2 & - & - & 10 & 10 & 10 & 10 & 10 & 10 & 10 & 10 & 0 \\
\hline 2 & 1 & 2 & 2 & 3 & 4 & 10 & 10 & 10 & 10 & 10 & 10 & 10 & 10 & 0 \\
\hline 2 & 2 & 2 & 2 & 3 & 4 & 10 & 10 & 10 & 10 & 10 & 1 & 1 & 10 & 0 \\
\hline 2 & 3 & 2 & 2 & 3 & 4 & 10 & 1 & 10 & 10 & 10 & 1 & 1 & 10 & 0 \\
\hline 2 & 4 & 2 & 2 & 3 & 4 & 10 & 1 & 10 & 10 & 10 & 10 & 10 & 10 & 1 \\
\hline 3 & 1 & - & - & - & 3 & 10 & 10 & 10 & 10 & 10 & 10 & 10 & 10 & 0 \\
\hline 3 & 2 & - & - & - & 3 & 10 & 10 & 10 & 10 & 10 & 10 & 10 & 10 & 0 \\
\hline 3 & 3 & - & - & - & 3 & 10 & 10 & 10 & 10 & 10 & 10 & 10 & 10 & 1 \\
\hline 4 & 1 & 3 & 3 & 8 & - & 10 & 10 & 10 & 10 & 10 & 10 & 10 & 10 & 0 \\
\hline 4 & 2 & 3 & 3 & 8 & - & 10 & 10 & 10 & 10 & 10 & 10 & 10 & 10 & 0 \\
\hline 4 & 3 & 3 & 3 & 8 & - & 1 & 10 & 10 & 10 & 10 & 10 & 10 & 1 & 0 \\
\hline 4 & 4 & 3 & 3 & 8 & - & 1 & 10 & 10 & 10 & 10 & 10 & 10 & 1 & 0 \\
\hline 4 & 5 & 3 & 3 & 8 & - & 10 & 10 & 10 & 10 & 10 & 10 & 10 & 10 & 0 \\
\hline 4 & 6 & 3 & 3 & 8 & - & 10 & 10 & 10 & 10 & 10 & 10 & 10 & 10 & 0 \\
\hline 4 & 7 & 3 & 3 & 8 & - & 10 & 10 & 10 & 10 & 10 & 10 & 10 & 10 & 0 \\
\hline 4 & 8 & 3 & 3 & 8 & - & 10 & 1 & 10 & 10 & 10 & 10 & 10 & 10 & 0 \\
\hline 4 & 9 & 3 & 3 & 8 & - & 10 & 1 & 10 & 10 & 10 & 10 & 10 & 10 & 0 \\
\hline 4 & 10 & 3 & 3 & 8 & - & 10 & 10 & 10 & 10 & 10 & 10 & 10 & 10 & 0 \\
\hline
\end{tabular}

Only Streptococcus spp. case 2, Streptococcus spp. case 3, Staphylococcus spp. case 1, Escherichia coli case 2, Klebsiella spp. case 1, no growth case 1, no growth case 2, and other case 1 are shown due to space restrictions.

${ }^{2}$ Index variables for cases of bacteria-specific CM (Streptococcus spp., Staphylococcus aureus, Staphylococcus spp., Escherichia coli, Klebsiella spp., Trueperella pyogenes, no growth, and other by case, although not all are shown here) had 2 levels: 1 = case of CM occurring in the current month of lactation or 1 mo after; $10=$ no case of CM occurring in the current month or more than 2 mo since the last CM case (in the same lactation). 
Table 3. Number of lactations, and median DIM of occurrence of a first, second, or third case of clinical mastitis (CM), mortality (dying), or being culled (sold) in the first 10 mo of lactation in 5 New York State Holstein herds

\begin{tabular}{lccccc}
\hline & & & & \multicolumn{2}{c}{$\begin{array}{c}\text { Second-or-greater lactations } \\
(\mathrm{n}=31,746)\end{array}$} \\
\cline { 2 - 3 } \cline { 5 - 6 } Item & Number & Median DIM & & Number & Median DIM \\
\hline First case of CM & 3,712 & 128 & & 11,388 & 103 \\
Second case of CM & 959 & 200 & & 4,352 & 159 \\
Third case of CM & 300 & 226 & & 1,816 & 190 \\
Mortality & 727 & 100 & & 2,855 & 74 \\
Culling & 2,523 & 269 & & 9,476 & 207 \\
\hline
\end{tabular}

herds in New York State. In primiparae (multiparae in parentheses), there were $3,712(11,388)$ first cases, $959(4,352)$ second cases, and $300(1,816)$ third cases of CM. The median DIM for mastitis occurrence for each case was greater for primiparous cows compared with multiparous cows. A trend was also observed for the median DIM of mortality (culling in parentheses): 100 (269) in primiparae compared with 74 (207) in multiparae (Table 3). The most common pathogens in both groups were Streptococcus spp., E. coli, and no growth (Table 4).

\section{Effect of Bacteria-Specific CM on Mortality in Primiparous Cows}

The fit statistics for the estimated model were as follows: -2 log-likelihood value of $6,747.03$ and Pear- son chi-squared/degrees of freedom value of 0.95 . The presence of a first case in the current month in milk (compared with the absence of a first case) generally put cows at greater risk of mortality in that month; this was seen particularly with a first case of Klebsiella spp., where cows were $\exp (1.51)=4.53(95 \%$ CI: 2.69-7.61) times more at risk of mortality than cows without a first case of Klebsiella spp. (Table 5; Figure 1A). This was followed by a first case of E. coli [relative risk $=\exp (1.20)=3.32(95 \%$ CI: 2.46-4.48) compared with the baseline of the absence of a first case of $E$. coli in the current month in milk]. Cows with a second or third case of $E$. coli were $\exp (1.1)=3.00$ (95\% CI: $1.42-6.36)$ times more at risk of mortality compared with cows without a second or third case of $E$. coli in the current month in milk. Cows with

Table 4. Distribution of pathogens causing clinical mastitis (CM) in 5 New York State dairy herds by lactation (first lactation and $\geq 2$ lactations) ${ }^{1}$

\begin{tabular}{lcc}
\hline & \multicolumn{2}{c}{ Number (lactation incidence risk \%) } \\
\cline { 2 - 3 } & $\begin{array}{r}\text { First lactation } \\
(\mathrm{n}=18,420)^{2}\end{array}$ & $\begin{array}{c}\text { Second-or-greater lactations } \\
(\mathrm{n}=31,746)^{3}\end{array}$ \\
\cline { 2 - 3 } Pathogen & $1,185(6.4)$ & $4,275(13.5)$ \\
\hline Streptococcus spp. & $393(2.1)$ & $974(3.1)$ \\
Staphylococcus aureus & $392(2.1)$ & $1,119(3.5)$ \\
Staphylococcus spp. & $1,046(5.7)$ & $4,040(12.7)$ \\
Escherichia coli & $278(1.5)$ & $1,844(5.8)$ \\
Klebsiella spp. & $139(0.8)$ & $332(1.0)$ \\
Trueperella pyogenes & $0(0)$ & $35(0.1)$ \\
Citrobacter & $1(0.005)$ & $50(0.2)$ \\
Enterobacter & $10(0.05)$ & $22(0.07)$ \\
Pseudomonas & $73(0.4)$ & $76(0.2)$ \\
Mycoplasma & $30(0.2)$ & $36(0.1)$ \\
Corynebacterium bovis & $87(0.5)$ & $216(0.7)$ \\
Yeast & $677(3.7)$ & $2,133(6.7)$ \\
Miscellaneous & $61(0.3)$ & $218(0.7)$ \\
Contamination & $378(2.1)$ & $1,073(3.4)$ \\
Unknown $^{4}$ & $1,141(6.2)$ & $4,363(13.7)$ \\
No growth $^{5}$ & $(20)$ &
\end{tabular}

${ }^{1}$ Total number of CM cases (first, second, and third) in which the pathogen was identified. A cow may have more than 1 pathogen in one case. In the table above, both are accounted for.

${ }^{2}$ The number of cows that started their first lactation.

${ }^{3}$ The number of cows that started their second-or-greater lactation.

${ }^{4}$ The etiologic agent was not identified in the cultured sample.

${ }^{5}$ No bacterial growth above the level of detection of our microbiological procedures was observed in the cultured sample; however, these cases exhibited clinical signs of mastitis. 
retained placenta or DA were also at greater risk of mortality [i.e., $\exp (1)=2.72(95 \%$ CI: $2.32-3.19)$ and $\exp (1.09)=3.00$ (95\% CI: 2.56-3.46), respectively]. Pregnancy had a protective effect [i.e., $\exp (-1.35)=$ 0.26 (95\% CI: $0.23-0.30)]$.

\section{Effect of Bacteria-Specific CM on Culling in Primiparous Cows}

The fit statistics for the estimated model were as follows: -2 log-likelihood value of $14,720.10$ and Pearson chi-squared/degrees of freedom value of 0.86 . The risk of culling generally increased with the presence of a case of bacteria-specific CM or 1 mo after (compared with an absence of bacteria-specific CM or more than 2 mo since a first case; Table 5; Figure 1B). This was observed among cows with a first case of T. pyogenes $[\exp (2.34)=10.38(95 \%$ CI: 8.41-12.81)], a first case of Klebsiella spp. $[\exp (1.90)=6.69$ (95\% CI: 5.53-8.08)], a first case of Staph. aureus $[\exp (1.56)=4.76(95 \%$ CI: $2.69-8.41)]$, a first case of $E$. coli $[\exp (1.13)=3.10$ (95\% CI: 2.69-3.56)], and a third case of Klebsiella spp. $[\exp (1.6)=4.95$ (95\% CI: 3.06-8.00)]. Pregnancy had a protective effect $[\exp (-1.86)=0.16(95 \% \mathrm{CI}$ : $0.15-0.17)]$ and cows with DA were $\exp (0.51)=1.67$ (95\% CI: 1.48-1.88) times more at risk of being culled compared with cows without DA. Culling risk was greater as cows were further in their lactation.

\section{Effect of Bacteria-Specific CM on Mortality in Multiparous Cows}

The fit statistics for the estimated model were as follows: -2 log-likelihood value of 24,601.80 and Pearson chi-squared/degrees of freedom value of 1.0. A first or second case of Streptococcus spp. had a protective effective on the risk of mortality (evidenced by negative parameter estimates; Table 6; Figure 2A). In general, however, the presence of a first or second/third case put cows at greater risk of mortality (compared with the absence of a first or second/third case). This was greatest for cows with a first case of Klebsiella spp. in the current month in milk $[\exp (1.32)=3.74$ (95\% CI: 3.29-4.26)], followed by a second/third case of Klebsiella spp. $[\exp (1.15)=3.16$ (95\% CI: 2.48-4.01)], a first case of E. coli $[\exp (1.1)=3.00$ (95\% CI: $2.72-3.32)]$, and a first case of other $\mathrm{CM}[\exp (0.57)=1.77(95 \%$ CI: $1.55-2.01)]$. As for the primiparous cow analysis, pregnancy had a protective effect and other diseases (retained placenta, DA, and milk fever) increased the risk of mortality. The risk was greatest in the summer (compared with winter): $\exp (0.16)=1.17$ (95\% CI: $1.12-1.23)$.

\section{Effect of Bacteria-Specific CM on Culling in Multiparous Cows}

The fit statistics for the estimated model were as follows: -2 log-pseudo-likelihood value of $1,647,275$ and generalized chi-squared/degrees of freedom value of 0.79 . The risk of culling increased for cows as they progressed through successive lactations [i.e., cows in parity $4+$ were $\exp (0.74)=2.10$ (95\% CI: $2.03-2.16$ ) times more likely to be culled compared with cows in lactation 2 (the baseline); Table 6]. As for primiparous cows, the culling risk was greater as cows progressed through their lactation. Pregnant cows were less likely to be culled compared with nonpregnant cows and ketosis and DA were risk factors for culling. As profitability increased, the likelihood of a cow being culled increased slightly. A $\$ 1$-profit increase resulted in a rise in risk of culling from $\exp (-3.47)=0.0311$ to $\exp (-3.47+$ $0.006 \times 1)=0.0313$. As net replacement cost increased, the probability of culling decreased slightly. A $\$ 100$ increase in net replacement cost produced a reduction in risk of culling from $\exp (-3.47)=0.0311$ to $\exp (-3.47$ $-0.00049 \times 100)=0.03$.

The risk of culling dependent on the cow's characteristics can be easily calculated from the parameter estimates in our tables by taking the exponential of the summation of the intercept plus the parameter estimates of interest. As an example, referring to Table 6 and Figure 2B, the risk of culling a cow that is in parity 4 , month in milk 5 , in summer, with a first case of $E$. coli, in the current month in milk (or 1 mo since a first case of $E$. coli) that is pregnant and without any other disease is calculated by $\exp (-3.47+0.74+0.59-0.09$ $+0.92-1.68)=0.05$ or $5 \%$.

\section{DISCUSSION}

The effect of CM on mortality and culling has been studied previously (Neerhof et al., 2000; Thomsen et al., 2004; Hertl et al., 2011); however, very few studies have examined the effect of bacteria-specific CM on mortality and culling, and in particular, the effect of repeated cases of bacteria-specific CM. This knowledge can help farmers identify which pathogens are responsible for the greatest culling and need particular attention. We quantified for the first time the combined effect of different cases of pathogens on the risk of culling, while also accounting for time since a case of bacteria-specific CM.

Based on the milk-loss estimates for each pathogen by cases that we have previously observed (Gröhn et al., 2004), among multiparous cows, as a general rule, milk losses were greatest in the same week, or soon after the occurrence of any bacteria-specific CM. Culling 
Table 5. Effects of the first 3 pathogen-specific clinical mastitis (CM) cases and other factors on mortality and culling in primiparous cows (18,420 lactations) in 5 New York State dairy farms over the first 10 mo of lactation $^{1,2}$

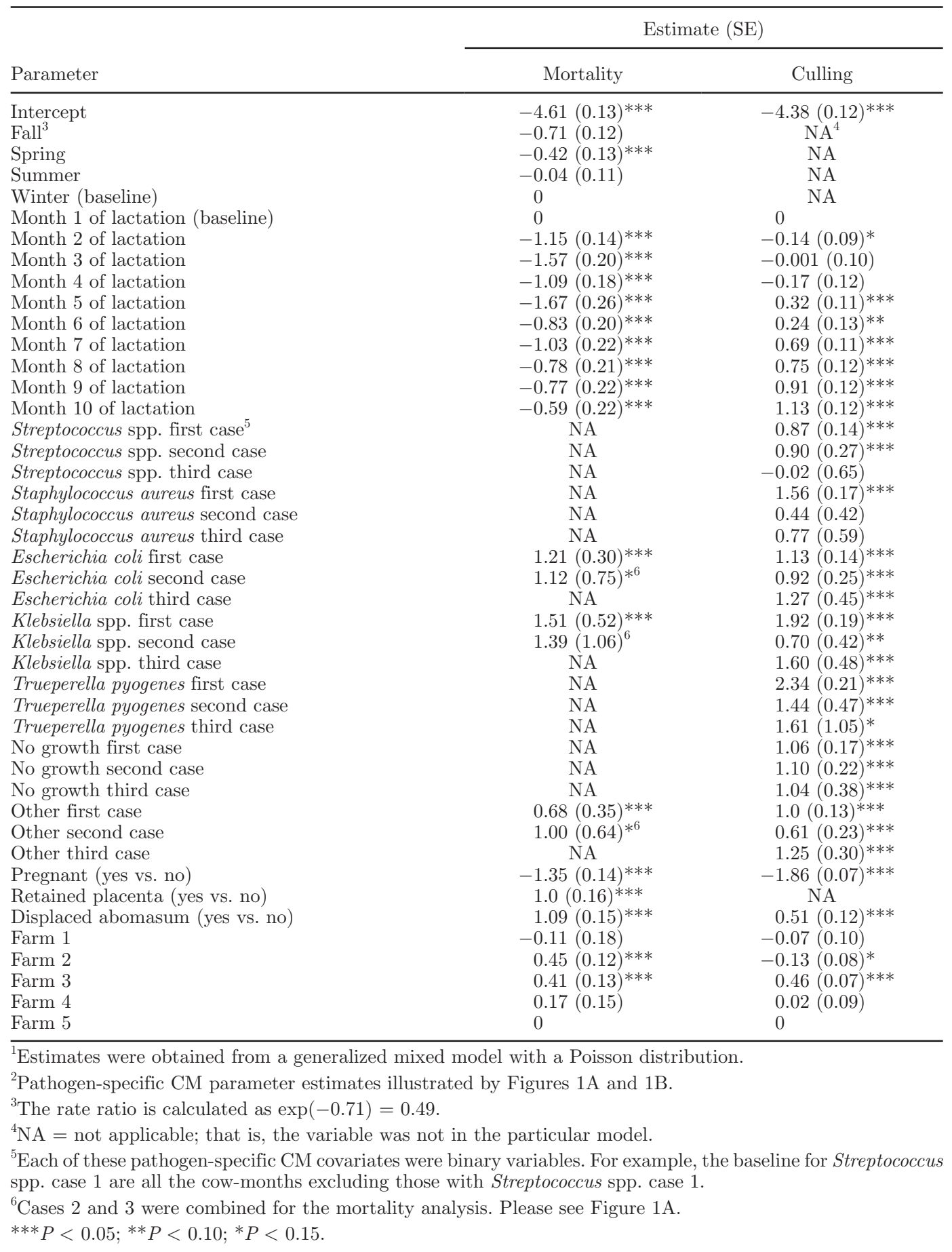

estimates of cows that have a first or second case of $E$. coli or Klebsiella spp. indicate greater risks of culling in the month in milk or 1 mo since these cases occur (i.e., a farmer is less likely to wait to cull these cows, which reflect an action taken due to the immediate milk losses experienced or the anticipated losses). It is difficult to compare directly, as the milk-loss models had a weekly time step, whereas the culling models have a monthly time step. Hence, it is possible that a case of CM could have occurred at the beginning or end of the month 

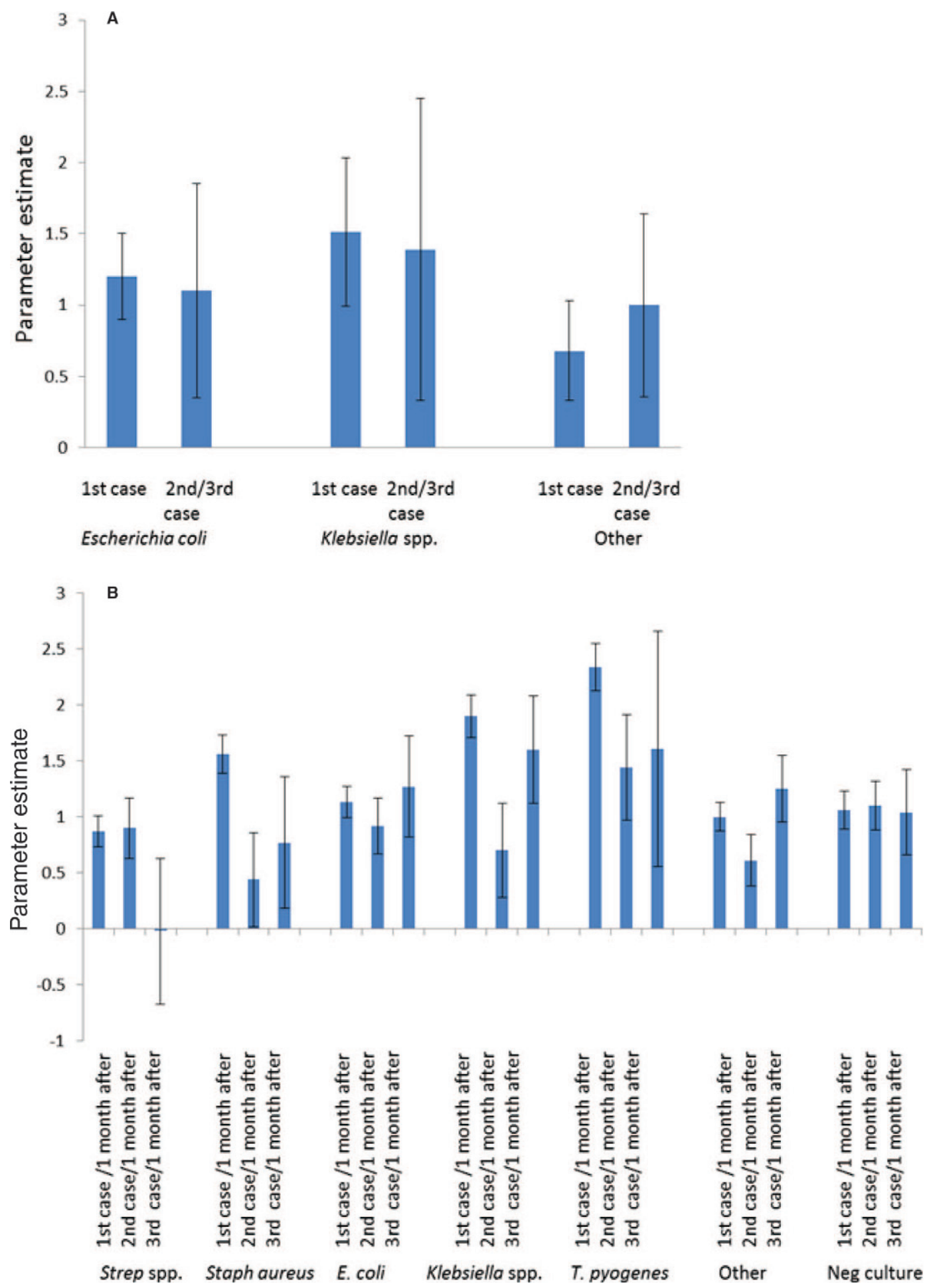

Figure 1. Parameter estimates (bar height is mean and interval is SE) of pathogen-specific clinical mastitis effects (by pathogen and case) among primiparous cows for mortality analysis (1A) and culling analysis (1B). Strep = Streptococcus; Staph $=$ Staphylococcus; T. $=$ Trueperella; Neg $=$ negative. Color version available in the online PDF.

and the milk loss associated with the CM case could be seen either within the same month or soon after in the following month, depending on when the CM occurred.
One of the few studies that examined the effect of pathogen-specific $\mathrm{CM}$ on culling, reported that all pathogens have significant effects on herd life, but par- 
Table 6. Effects of the first 3 pathogen-specific clinical mastitis (CM) cases and other factors on mortality and culling in multiparous cows (31,746 lactations) in 5 New York State dairy farms over the first 10 mo of lactation $^{1,2}$

\begin{tabular}{|c|c|c|}
\hline \multirow[b]{2}{*}{ Parameter } & \multicolumn{2}{|c|}{ Estimate (SE) } \\
\hline & Mortality & Culling \\
\hline Intercept & $-4.50(0.07)^{* * *}$ & $-3.47(0.14)^{* * *}$ \\
\hline Parity 2 (baseline) & 0 & 0 \\
\hline Parity 3 & $0.44(0.05)^{* * *}$ & $0.39(0.03)^{* * *}$ \\
\hline Parity 4 & $0.72(0.05)^{* * *}$ & $0.74(0.03)^{* * *}$ \\
\hline Fall $^{3}$ & $-0.15(0.06)^{* * *}$ & $-0.06(0.03)^{*}$ \\
\hline Spring & $-0.09(0.06)^{*}$ & $-0.11(0.03)^{* * *}$ \\
\hline Summer & $0.16(0.05)^{* * *}$ & $-0.09(0.03)^{* * *}$ \\
\hline Winter (baseline) & 0 & 0 \\
\hline Month 1 of lactation (baseline) & 0 & 0 \\
\hline Month 2 of lactation & $-0.90(0.07)^{* * *}$ & $-0.25(0.05)^{* * *}$ \\
\hline Month 3 of lactation & $-0.90(0.08)^{* * *}$ & $-0.04(0.05)$ \\
\hline Month 4 of lactation & $-0.93(0.09)^{* * *}$ & $0.23(0.05)^{* * *}$ \\
\hline Month 5 of lactation & $-0.89(0.09)^{* * *}$ & $0.59(0.05)^{* * *}$ \\
\hline Month 6 of lactation & $-0.94(0.10)^{* * *}$ & $0.74(0.05)^{* * *}$ \\
\hline Month 7 of lactation & $-0.73(0.10)^{* * *}$ & $0.98(0.05)^{* * *}$ \\
\hline Month 8 of lactation & $-0.68(0.11)^{* * *}$ & $1.24(0.05)^{* * *}$ \\
\hline Month 9 of lactation & $-0.74(0.11) * * *$ & $1.36(0.05)^{* * *}$ \\
\hline Month 10 of lactation & $-0.56(0.11)^{* * *}$ & $1.36(0.05)^{* * *}$ \\
\hline Streptococcus spp. first case ${ }^{4}$ & $-0.57(0.22)^{* * *}$ & $0.39(0.06)^{* * *}$ \\
\hline Streptococcus spp. second case & $-1.06(0.52)^{* * * 5}$ & $0.12(0.09)$ \\
\hline Streptococcus spp. third case & $\mathrm{NA}^{6}$ & $0.54(0.13)^{* * *}$ \\
\hline Staphylococcus aureus first case & NA & $0.93(0.11)^{* * *}$ \\
\hline Staphylococcus aureus second case & NA & $0.61(0.15)^{* * *}$ \\
\hline Staphylococcus aureus third case & NA & $0.40(0.25)$ \\
\hline Staphylococcus spp. first case & $0.30(0.27)$ & $0.41(0.11)^{* * *}$ \\
\hline Staphylococcus spp. second case & $1.01(0.37)^{* * * 5}$ & $-0.007(0.18)$ \\
\hline Staphylococcus spp. third case & NA & $0.41(0.24)$ \\
\hline Escherichia coli first case & $1.10(0.1)^{* * *}$ & $0.92(0.05)^{* * *}$ \\
\hline Escherichia coli second case & $0.65(0.23)^{* * * 5}$ & $0.69(0.09)^{* * *}$ \\
\hline Escherichia coli third case & NA & $0.76(0.14)^{* * *}$ \\
\hline Klebsiella spp. first case & $1.32(0.13)^{* * *}$ & $1.49(0.06)^{* * *}$ \\
\hline Klebsiella spp. second case & $1.15(0.24)^{* * * 5}$ & $0.81(0.10)^{* * *}$ \\
\hline Klebsiella spp. third case & NA & $0.74(0.14)^{* * *}$ \\
\hline Trueperella pyogenes first case & NA & $1.75(0.11)^{* * *}$ \\
\hline Trueperella pyogenes second case & NA & $1.29(0.19)^{* * *}$ \\
\hline Trueperella pyogenes third case & NA & $1.17(0.34)^{* * *}$ \\
\hline No growth first case & NA & $0.57(0.06)^{* * *}$ \\
\hline No growth second case & NA & $0.38(0.09)^{* * *}$ \\
\hline No growth third case & NA & $0.73(0.11)^{* * *}$ \\
\hline Other first case & $0.57(0.13)^{* * *}$ & $0.48(0.06)^{* * *}$ \\
\hline Other second case & $0.37(0.24)^{* 5}$ & $0.55(0.08)^{* * *}$ \\
\hline Other third case & NA & $0.62(0.12)^{* * *}$ \\
\hline Pregnant (yes vs. no) & $-1.21(0.07)^{* * *}$ & $-1.68(0.03)^{* * *}$ \\
\hline Retained placenta (ves vs. no) & $0.67(0.07)^{* * *}$ & $-0.37(0.11)^{* * *}$ \\
\hline Displaced abomasum (yes vs. no) & $0.47(0.08)^{* * *}$ & $0.25(0.05)^{* * *}$ \\
\hline Milk fever (yes vs. no) & $1.70(0.09)^{* * *}$ & NA \\
\hline Ketosis (yes vs. no) & NA & $0.12(0.04)^{* * *}$ \\
\hline Farm 1 & $-0.05(0.09)$ & \\
\hline Farm 2 & $0.66(0.06)^{* * *}$ & \\
\hline Farm 3 & $0.68(0.06)^{* * *}$ & Herd included as \\
\hline Farm 4 & $0.29(0.07)^{* * *}$ & random effect \\
\hline Farm 5 & 0 & \\
\hline
\end{tabular}

${ }^{1}$ Estimates were obtained from a generalized mixed model with a Poisson distribution.

${ }^{2}$ Pathogen-specific CM parameter estimates illustrated by Figures $2 \mathrm{~A}$ and $2 \mathrm{~B}$.

${ }^{3}$ The rate ratio is calculated as $\exp (-0.15)=0.86$.

${ }^{4}$ Each of these pathogen-specific CM covariates were binary variables. For example, the baseline for Streptococcus spp. case 1 is all the cow-months excluding those with Streptococcus spp. case 1.

${ }^{5}$ Cases 2 and 3 were combined for the mortality analysis. Please see Figure $2 \mathrm{~A}$.

${ }^{6} \mathrm{NA}==$ not applicable; that is, the variable was not in the particular model.

*** $P<0.05 ;{ }^{*} P<0.15$. 

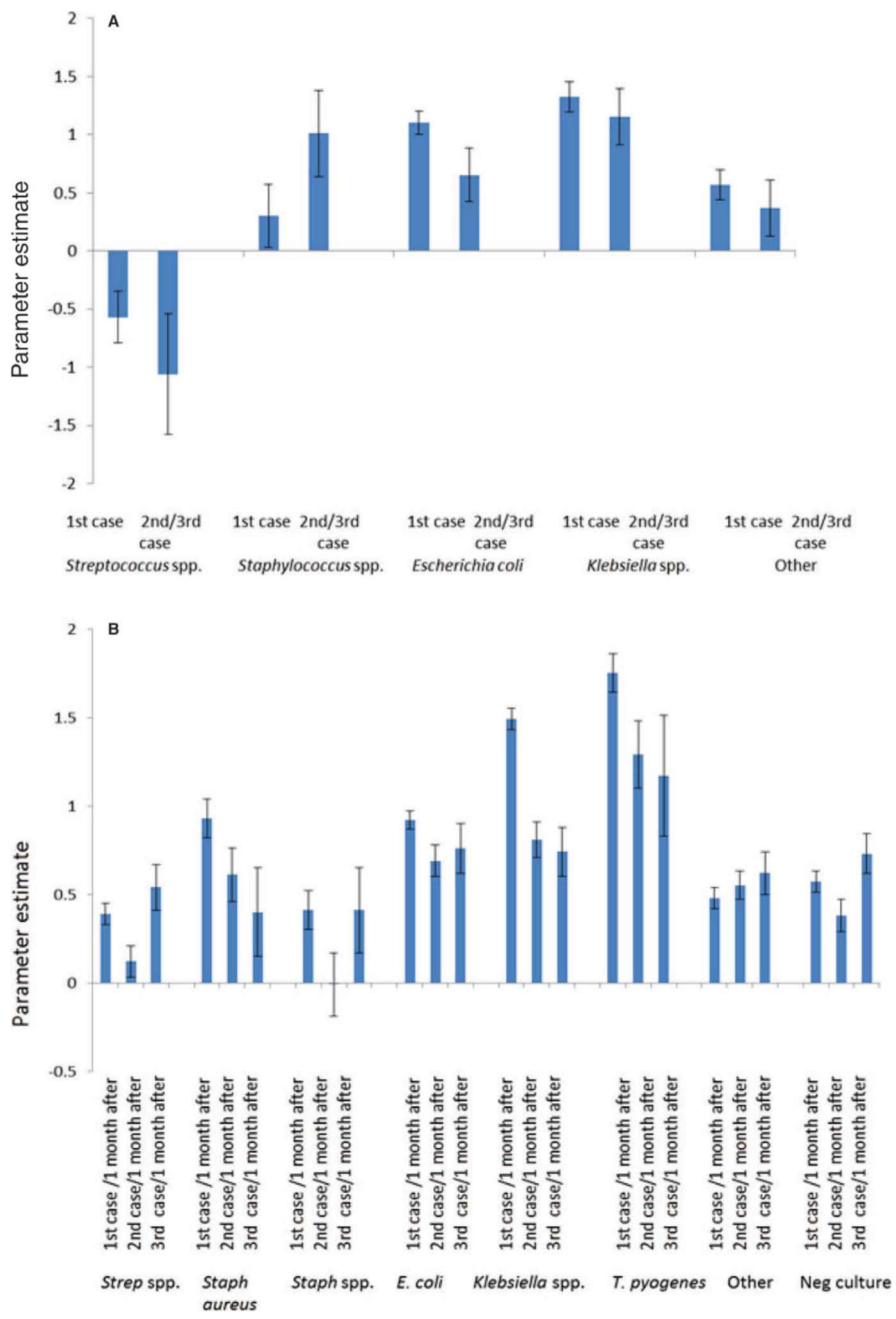

Figure 2. Parameter estimates (bar height is mean and interval is SE) of bacteria-specific clinical mastitis effects (by pathogen and case) among multiparous cows in mortality analyses $(2 \mathrm{~A})$ and culling analyses (2B). T. = Trueperella; Neg = negative. Color version available in the online PDF. 
ticularly Staphylococcus spp., E. coli, Klebsiella spp., and T. pyogenes (Gröhn et al., 2005). The authors concluded that it was surprising that the Staphylococcus spp. culling hazard ratios (HR) were so high and, in our current study we found that the risk of culling among Staphylococcus spp.-infected cows was low compared with other pathogens as would be expected, based on its effect on linear score and income (Wilson et al., 1997). Hence, with the exception of Staphylococcus spp., we found that the risk of culling was greatest among the same pathogens as described in Gröhn et al. (2005). In the case of our multiparous culling analysis, we identified that Staph. aureus was within the top 4 pathogens that resulted in culling of cows. Although this pathogen was not one of the primary pathogens resulting in culling in the study by Gröhn et al. (2005), it was discovered that when Staph. aureus CM was diagnosed after 62 DIM, the HR for culling was 5.4 times higher, compared with nonmastitic cows, and did not change over time. Whist et al. (2009) found that cows with Staph. aureus had significantly higher SCC than culture-negative cows and that the HR of culling in cows with Staph. aureus in at least 1 quarter was 1.7 (1.51.9). It was somewhat surprising to see the low risk of mortality in multiparous cows affected with streptococcal mastitis. These multiparous animals showed a lower risk of culling compared with nonmastitic herd mates if they had experienced a case of streptococcal mastitis. It may be suggested that streptococcal mastitis is relatively easy to cure and typically animals that will get a case of streptococcal mastitis are out-producing their herd mates (Gröhn et al., 2004). Similarly, the risk of mortality in Staphylococcus spp.-affected cows was also not significant, or only slightly higher compared with nonaffected herd mates (Figure 2A).

In our study, we found that E. coli was within the top 4 pathogens resulting in culling among both primiparous and multiparous cows. The significance of the relationship between $E$. coli mastitis and fatality was also demonstrated by Hazlett et al. (1984); E. coli was isolated in pure culture in $47.3 \%$ of fatal mastitis cases. Klebsiella spp. was found to be the second-mostcommon cause of fatal mastitis in that study, which mirrors our current results.

In primiparae and multiparae, DA was a risk factor for mortality, as well as milk fever (among multiparae). Among all cows, DA was a risk factor for culling. We also found that the risks of culling among multiparae were greater for the coliforms compared with Staphylococcus and Streptococcus spp. These findings are similar to those of Thomsen et al. (2004); based on data from the Danish Cattle Database and a questionnaire study, those authors identified the most frequent diagnosis among udder/teat disorders resulting in unassisted death or euthanasia to be septicemic mastitis caused by $E$. coli. Milk fever constituted the majority of diagnoses among metabolic disorders and left and right DA constituted the majority of diagnoses among digestive disorders.

The increase in the risk of culling we observed from approximately mo 6 (Tables 5 and 6 ) could be explained by an open (nonpregnant) status having an effect on culling. The precise effect of an open status was difficult to discern, as we were unable to estimate an interaction between month in milk and pregnancy status due to lack of estimation convergence of our statistical models. It is, therefore, unclear if the increase in risk of culling is definitively due to the additional effect of conception status or may be partly due to other replacement reasons such as low milk production, high SCC, or other reasons. In a study by Rajala-Schultz and Gröhn (1999), the authors identified that the later in lactation a farmer knew a cow was pregnant, the higher her risk of being culled. Dechow and Goodling (2008) showed that as lactation progressed, reproduction became a more common reason for disposal (and the proportion of cows that died or were injured decreased). In a study by Esslemont and Kossaibati (1997), poor fertility was the single most important reason for involuntary culling regardless of the cow's age, with $36.5 \%$ of disposals due to poor fertility.

The culling risks that are seen at the beginning of lactation are likely to be due to the incidence of disease at the beginning of lactation. This is in agreement with the increase in risk of $\mathrm{CM}$ often seen at the beginning of lactation, soon after the dry period (Green et al., 2002). Dechow and Goodling (2008) found that most cows culled by 60 DIM had compromised health or were injured. The increase in mortality also seen at the beginning of lactation may also be explained by the composition of cases in that period of time. For example, Bradley and Green (2001) reported a trend toward more severe mastitis occurring in the first $90 \mathrm{~d}$ of lactation (14 of 167 cases) than in the rest of lactation (4 of $140 ; P=0.09$ ).

We observed that the cows with $\mathrm{CM}$ in parity 1 had a decrease in risk of culling between mo 3 and 6 . Similarly, Neerhof et al. (2000) reported that the risk of culling due to mastitis increased with an increase in the stage of lactation, with the exception of diseased cows in parity 1 , which had the lowest risk of culling in the second stage (60-180 d) of lactation.

We did not include milk yield, as it is an intervening variable between mastitis and culling, and in early lactation, cows have higher milk production, so culling is less likely compared with late lactation when milk production tapers off (Gröhn et al., 2005). Although milk yield was not included in our models, by including 
the stage of lactation (i.e., month in milk), this variable was associated with many factors including milk yield (Gröhn et al., 2005). From our parameter estimates, we observe that as month in milk increases, so does the risk of culling.

When a bacteria-specific CM variable encompassing all cases was used, model convergence was not attainable. This was unlike the case in which binary mastitis variables were included and these models have been presented here. The advantage of the former coding scheme, however, is that the baseline remains the same within a bacteria-specific CM. For this reason, throughout this paper, we have specified what baseline the relative risks are in comparison to; these baselines include clinically mastitis-free cow-months, mastitis cases (at lower frequency), cow-months without the pathogen of interest, and subclinical cases.

Several advantages and disadvantages exist that arise as a result of how we have defined our reference group. By working at the farmer's level of CM identification, we had access to a large number of observations; however, this meant that we were unable to monitor udder health under scientific circumstances (i.e., quarter foremilk SCC threshold of 100,000 cells/mL and culturing of results). Further, it was assumed that cows with signs of $\mathrm{CM}$ that had no cultivated pathogens were not $\mathrm{CM}$ cases caused by trauma, but rather due to pathogens that simply could not be identified by culture (whereby one reason for this may be contamination). Had the focus of this study been cows with all mastitis types (both clinical and subclinical), it would be expected that the results against the baseline group of truly mastitis-free cows (i.e., free of both clinical and subclinical mastitis) would have been even more striking.

\section{CONCLUSIONS}

This study quantifies the effect of bacteria-specific CM, by case, on mortality and culling among primiparous and multiparous cows. This provides farmers with information relating to which specific pathogens contribute to mortality and culling and where focus needs to be placed for improvements in management practices. Increases in the risk of mortality and culling were observed across all pathogens, but particularly among cases of Klebsiella spp., E. coli, and T. pyogenes, buttressing our understanding of the severity of these pathogens and their effects on the bovine udder. The mortality risks of these models will be incorporated into a bacteria-specific economic optimization model, aimed at calculating the cost of bacteria-specific CM, and providing economically optimal decisions for dairy farmers with diseased cows.

\section{ACKNOWLEDGMENTS}

This project was supported by the Agriculture and Food Research Initiative Competitive Grant no. 201065119-20478 from the USDA National Institute of Food and Agriculture. The authors thank the owners and personnel from the 5 dairies, and the personnel of the Ithaca (NY), Canton (NY), and Geneseo (NY) Regional Laboratories of Quality Milk Production Services for their valuable cooperation.

\section{REFERENCES}

Bar, D., Y. T. Gröhn, G. Bennett, R. N. González, J. A. Hertl, H. F. Schulte, L. W. Tauer, F. L. Welcome, and Y. H. Schukken. 2008a. Effects of repeated episodes of generic clinical mastitis on mortality and culling in dairy cows. J. Dairy Sci. 91:2196-2204. http:// dx.doi.org/10.3168/jds.2007-0460.

Bar, D., L. W. Tauer, G. Bennett, R. N. González, J. A. Hertl, Y. H. Schukken, H. F. Schulte, F. L. Welcome, and Y. T. Gröhn. 2008b. The cost of generic clinical mastitis in dairy cows as estimated by using dynamic programming. J. Dairy Sci. 91:2205-2214. http:// dx.doi.org/10.3168/jds.2007-0573.

Barkema, H. W., Y. H. Schukken, T. J. Lam, M. L. Beiboer, H. Wilmink, G. Benedictus, and A. Brand. 1998. Incidence of clinical mastitis in dairy herds grouped in three categories by bulk milk somatic cell counts. J. Dairy Sci. 81:411-419.

Bradley, A. J., and M. J. Green. 2001. Aetiology of clinical mastitis in six Somerset dairy herds. Vet. Rec. 148:683-686.

Cha, E., D. Bar, J. A. Hertl, L. W. Tauer, G. Bennett, R. N. González, Y. H. Schukken, F. L. Welcome, and Y. T. Gröhn. 2011. The cost and management of different types of clinical mastitis in dairy cows estimated by dynamic programming. J. Dairy Sci. 94:44764487. http://dx.doi.org/10.3168/jds.2010-4123.

Dechow, C. D., and R. C. Goodling. 2008. Mortality, culling, by sixty days in milk, and production profiles in high- and low-survival Pennsylvania herds. J. Dairy Sci. 91:4630-4639. http://dx.doi. org/10.3168/jds.2008-1337.

Esslemont, R. J., and M. A. Kossaibati. 1997. Culling in 50 dairy herds in England. Vet. Rec. 140:36-39.

Green, M. J., L. E. Green, G. F. Medley, Y. H. Schukken, and A. J. Bradley. 2002. Influence of dry period bacterial intramammary infection on clinical mastitis in dairy cows. J. Dairy Sci. 85:25892599.

Gröhn, Y. T., S. W. Eicker, V. Ducrocq, and J. A. Hertl. 1998. Effect of diseases on the culling of Holstein dairy cows in New York State. J. Dairy Sci. 81:966-978.

Gröhn, Y. T., R. N. González, D. J. Wilson, J. A. Hertl, G. Bennett, H. Schulte, and Y. H. Schukken. 2005. Effect of pathogen-specific clinical mastitis on herd life in two New York State dairy herds. Prev. Vet. Med. 71:105-125.

Gröhn, Y. T., D. J. Wilson, R. N. González, J. A. Hertl, H. Schulte, G. Bennett, and Y. H. Schukken. 2004. Effect of pathogen-specific clinical mastitis on milk yield in dairy cows. J. Dairy Sci. 87:3358-3374.

Halasa, T., M. Nielen, R. B. M. Huirne, and H. Hogeveen. 2009. Stochastic bio-economic model of bovine intramammary infection. Livest. Sci. 124:295-305.

Hazlett, M. J., P. B. Little, M. G. Maxie, and D. A. Barnum. 1984. Fatal mastitis of dairy cows: A retrospective study. Can. J. Comp. Med. 48:125-129.

Hertl, J. A., Y. T. Gröhn, J. D. G. Leach, D. Bar, G. J. Bennett, R. N. González, B. Rauch, F. L. Welcome, L. W. Tauer, and Y. H. Schukken. 2010. Effects of clinical mastitis caused by grampositive and gram-negative bacteria and other organisms on the probability of conception in New York State Holstein dairy cows. J. Dairy Sci. 93:1551-1560. http://dx.doi.org/10.3168/jds.20092599 . 
Hertl, J. A., Y. H. Schukken, D. Bar, G. J. Bennett, R. N. González, B. J. Rauch, F. L. Welcome, L. Tauer, and Y. T. Gröhn. 2011. The effect of recurrent episodes of clinical mastitis caused by gram-positive and gram-negative bacteria and other organisms on mortality and culling in Holstein dairy cows. J. Dairy Sci. 94:4863-4877. http://dx.doi.org/10.3168/jds.2010-4000.

Houben, E. H. P., R. B. M. Huirne, A. A. Dijkhuizen, and A. R. Kristensen. 1994. Optimal replacement of mastitic cows determined by a hierarchical Markov process. J. Dairy Sci. 77:2975-2993.

Lehtolainen, T., S. Suominen, T. Kutila, and S. Pyörälä. 2003. Effect of intramammary Escherichia coli endotoxin in early vs. latelactation dairy cows. J. Dairy Sci. 86:2327-2333.

Maatje, K., P. J. M. Huijsmans, W. Rossing, and P. H. Hogewerf. 1992. The efficacy of in-line measurement of quarter milk electrical conductivity, milk yield and milk temperature for the detection of clinical and subclinical mastitis. Livest. Prod. Sci. 30:239-249.

Neerhof, H. J., P. Madsen, V. P. Ducrocq, A. R. Vollema, J. Jensen, and I. R. Korsgaard. 2000. Relationships between mastitis and functional longevity in Danish black and white dairy cattle estimated using survival analysis. J. Dairy Sci. 83:1064-1071.

Nielen, M., Y. H. Schukken, A. Brand, S. Haring, and R. T. FerwerdaVan Zonneveld. 1995. Comparison of analysis techniques for online detection of clinical mastitis. J. Dairy Sci. 78:1050-1061. http://dx.doi.org/10.3168/jds.S0022-0302(95)76721-2.

Norberg, E., H. Hogeveen, I. R. Korsgaard, N. C. Friggens, K. H. M. N. Sloth, and P. Løvendahl. 2004. Electrical conductivity of milk: Ability to predict mastitis status. J. Dairy Sci. 87:1099-1107. http://dx.doi.org/10.3168/jds.S0022-0302(04)73256-7.

Rajala-Schultz, P. J., and Y. T. Gröhn. 1999. Culling of dairy cows. Part III. Effects of diseases, pregnancy status and milk yield on culling in Finnish Ayrshire cows. Prev. Vet. Med. 41:295-309.

Rothman, K. J. 1986. Modern Epidemiology. 1st ed. Little, Brown and Co., Boston, MA/Toronto, ON, Canada.

SAS Institute. 2008. User's Guide. Version 9.2. SAS Institute Inc., Cary, NC.

Schukken, Y. H., D. Bar, J. Hertl, and Y. T. Gröhn. 2010. Correlated time to event data: Modeling repeated clinical mastitis data from dairy cattle in New York State. Prev. Vet. Med. 97:150-156. http://dx.doi.org/10.1016/j.prevetmed.2010.09.012.

Schukken, Y. H., J. Hertl, D. Bar, G. J. Bennett, R. N. González, B. J. Rauch, C. Santisteban, H. F. Schulte, L. Tauer, F. L. Welcome, and Y. T. Gröhn. 2009. Effects of repeated gram-positive and gram-negative clinical mastitis episodes on milk yield loss in Holstein dairy cows. J. Dairy Sci. 92:3091-3105. http://dx.doi. org/10.3168/jds.2008-1557.

Sørensen, L. P., T. Mark, M. K. Sørensen, and S. Østergaard. 2010. Economic values and expected effect of selection index for pathogen-specific mastitis under Danish conditions. J. Dairy Sci. 93:358-369. http://dx.doi.org/10.3168/jds.2009-2506.

Thomsen, P. T., A. M. Kjeldsen, J. T. Sørensen, and H. Houe. 2004. Mortality (including euthanasia) among Danish dairy cows (19902001). Prev. Vet. Med. 62:19-33.

USDA-ERS (US Department of Agriculture Economic Research Service). 2010. Monthly milk costs of production. Accessed Jan. 17, 2011. http://www.ers.usda.gov/Data/CostsAndReturns/TestPick. htm\#milkproduction.

USDA-ERS (US Department of Agriculture Economic Research Service). 2012. Commodity costs and returns. Accessed Mar. 1, 2012. http://www.ers.usda.gov/data/costsandreturns/testpick. htm\#milkproduction.

USDA-NASS (US Department of Agriculture National Agricultural Statistics Service). 2012. Quick stats. Accessed Mar. 1, 2012. http://quickstats.nass.usda.gov.

Whist, A. C., O. Osterås, and L. Sølverød. 2009. Association between isolation of Staphylococcus aureus one week after calving and milk yield, somatic cell count, clinical mastitis, and culling through the remaining lactation. J. Dairy Res. 76:24-35.

Wilson, D. J., R. N. González, and H. H. Das. 1997. Bovine mastitis pathogens in New York and Pennsylvania: Prevalence and effects on somatic cell count and milk production. J. Dairy Sci. 80:2592-2598. 